\title{
Determinants of Dividend Payout: An Empirical Study of Pharmaceutical Companies of Pakistan Stock Exchange (PSX)
}

\author{
Farman Ali Khan and Nawaz Ahmad \\ IoBM, Karachi, Pakistan \\ Correspondence should be addressed to: Farman Ali Khan; std_18145@iobm.edu.pk
}

Received date: 5 September 2016; Accepted date: 7 February 2017; Published date: 7 March 2017

Academic Editor: Umara Noreen

Copyright (c) 2017. Farman Ali Khan and Nawaz Ahmad. Distributed under Creative Commons CC-BY 4.0

\begin{abstract}
The objective of this research is to determine the impact of profitability, growth opportunities, risk, liquidity, firm size, leverage, taxation and audit type on dividend payout in order to increase understanding of the determinants of dividend payout within Pakistani corporate environment. To meet the objective of this research, five year financial data from 2009-2014 of listed pharmaceutical companies is used and analyzed to determine the impact of selected variables on dividend payout. Correlation analysis and backward multiple linear regression is applied on the data to determine the association between variables and the impact of selected independent variables on dividend payout. Findings reveal that audit type, liquidity, growth opportunities \& profitability are the key determinants of dividend payout of pharmaceutical companies of PSX. 31.90\% variation in dividend payout is caused by these variables. Other independent variables including taxation, risk, firm size and leverage insignificantly influence dividend payout decisions of pharmaceutical companies of PSX.
\end{abstract}

Keywords: Dividend Payout, profitability, growth opportunities, risk, liquidity, firm size, leverage, taxation and audit type.

\section{Introduction}

Dividend payout decision tends to focus on the distribution of the corporate profits as a whole or holding some part of it. Dividend payout is one of the sizzling topics that always gain attention of organizations, financial analyst, researchers, investors and other stakeholders. According to Brealy et.al, (2008) dividend policy controversy is one of the ten major unsolved problems of corporate finance which deserves more research in order to increase understanding of the subject.

A number of research studies are conducted on this topic globally; however 
no general consensus is found among them. Frenco Modigliani together with coresearcher Merton Miller stated 'irrelevance of dividends' which gain a lot of attention. According to them, companies' dividend policy is irrelevant in perfect capital market and investors are more interested in the investment policy of the company rather than the dividend policy.

In contrary, numerous researchers believe that perfect capital market does not exist and various real world factors influence company's dividend payout policy (Mehta, 2012, Nuhu, 2014, Maladjian \& Khoury, 2014, Rafique, 2012, Gill, Biger \& Tibrewala, 2010).

\section{Scope of the Study}

A number of researchers prove that dividend payout decision is influenced by various factors; it is worthwhile for the stakeholders of a company to understand factors that influence company's dividend payout decisions. This research is expected to increase understanding of the determinants of dividend payout within Pakistani corporate environment.

\section{Objective of the Study}

The objective of this research is to examine the impact of selected factors including profitability, growth opportunities, risk, liquidity, firm size, leverage, taxation and audit type on dividend payout decision of Pharmaceutical companies listed on Pakistan Stock Exchange.

\section{Research Problem and knowledge gap}

Dividend payout policy is the most controversial topic within the context of corporate finance. According to Brealy et.al, (2008) dividend policy controversy is one of the ten major unsolved problems of corporate finance which deserves more research in order to increase understanding of the subject. A number of research studies are conducted in this area globally however no general consensus is found among them.

Research conducted within the same country, incorporating almost the same variables but different industries, has come up with somewhat different results. Gill, Biger, \& Tibrewala (2010) studies taking into account manufacturing and service industry of America have concluded different significant factors for both industries. Therefore this research has chosen pharmaceutical industry, a major industry within Pakistan's corporate environment, in order to find industrial specific factor influencing dividend payout.

Despite the above considerations, it is also found that some variables effecting dividend payout are perceived to be affecting it in similar direction. Such as if there is increase in profitability of a firm it would be assumed and proved to increase dividend payout ratio of any corporation (Mehta,2012, Nuhu, 2014,Gill, Biger, \& Tibrewala 2010,Zameer et al 2013) but this relationship is being rejected by Jozwiak (2014) studies. Same is the case with liquidity. Some researchers have concluded positive relationship (Ahmed and Javaid 2009) while some have come up with negative relationship (Zamer et al 2013). These conflicting results demand more research that could clarify such relationships.

\section{Hypotheses}

The followings are the hypotheses of this research:

H1: Profitability has no impact on dividend payout.

H2: Growth opportunities have no impact on dividend payout.

H3: Risk has no impact on dividend payout.

H4: Liquidity has no impact on dividend payout.

H5: Firm size has no impact on dividend payout.

H6: Leverage has no impact on dividend payout.

H7: Taxation has no impact on dividend payout. 
H8: Audit type has no impact on dividend payout.

\section{Literature Review}

Mehta (2012)examined the impact of risk, size, profitability, liquidity and leverage of firm on dividend payout. The industries investigated includeconstruction, real estate, energy, health care and telecommunication sector industries listed in Abu Dhabi Stock Exchange for a five years period starting from 2005 to 2009 . Findings reveal that profitability and size are the key factors in significantly changing dividend payout decision.

Nuhu (2014)investigated the impact of profitability, investment opportunity sets, taxation, leverage, firm size, board size, board independence and audit type on dividend payout ratio. It was concluded that profitability, leverage, board independence, audit type, and board size are the key factors that significantly influence dividend payout in Ghana.

Maladjian \& Khoury (2014) explored the impact of profitability, growth, liquidity and size of firm, leverage, risk, and previous year's dividends on dividend policy of Lebanese banks registered on Beirut Stock Exchange. They concluded that out of seven variables studied, five variables are statistically significant whereas profitability and liquidity are statistically insignificant.

Rafique (2012) examined the influence of size of firm, earnings, leverage, growth, profitability and corporate tax on dividend policy of Non-Financial firms listed in KSE100 index. She concluded that out of the six variables examined, only two variables including corporate tax and firm size are found to be significant. The rest are insignificant in the context of Pakistani markets.

Gill, Biger, \& Tibrewala (2010) studied the influence of profitability, growth, taxes, cash flow, risk and leverage on dividend payout ratio in the context service and manufacturing firms of America. They concluded that for service firms, dividend policy is influenced by growth, profitability and leverage. For manufacturing firms, dividend policy is influenced by taxes, profitability, and risk.

Jozwiak (2014) investigated the factors influencing dividend policy of nonfinancial listed companies of Warsaw Stock Exchange of Poland. The factors studied include leverage, liquidity, profitability, size and risk. Findings reveal negative impact of leverage and profitability on dividend payout i.e. firms with high profitability pay low dividend to retain capital for future investment. Firms with high leverage pay low dividend due to high interest payments.

Alzomaia \& AlKhadhiri (2013) examine the factors influencing dividend policy of nonfinancial listed companies of Saudi Arabia Stock Exchange (TASI). The factors studied include past dividend, earning per share, growth, leverage and size of firm. They found positive relationship of profitability and last year dividend with dividend payout decision. Companies pay more dividend when they experience increase in their profitability. Last year dividend payment is also considered important in deciding dividend payout.

Zameer et al (2013) examined the influence of selected variables on dividend policy of foreign and domestic banks listed at various stock exchanges of Pakistan. The factors studied include profitability, firm size, leverage, growth, and liquidity, agency cost, past dividend, risk, and ownership structure of the banks. Only four factors are found to have significant impact on dividend policy of banks. Profitability, past dividend and ownership structure have positive relationship with dividend payout whereas liquidity has negative relationship with dividend payout of banking sector. The rest of the factors studied are found be insignificant and have no impact on dividend decision.

Arif \& Akbar (2013) studied the impact of five factors including profitability, size, tax, growth and lifecycle stage on dividend payout of nonfinancial firms of Pakistan. 
They found that all factors significantly influence dividend payout. Profitability, size and investment opportunities positively influence dividend payout whereas tax negatively influences dividend payment decisions.

Kania \& Bacon (2005) investigated the influence of selected variables on dividend policy of 543 firms using ordinary least square regression. They found that growth, expansion, risk, organizational and insider ownership are negatively associated with dividend policy. Positive relationship is found between debt to total asset ratio and dividend payout.

Khan, Burton \& Power (2011) examined the view of different managers on dividend policy in Pakistan. Semi structured interview of 23 officials of Pakistani organization is conducted for the study. Findings reveal that dividend payout decisions in Pakistan are similar to developed countries like USA in many respects. However past years dividends do not alter current year dividend decision in Pakistan. The key determinants of dividend decision are liquidity and current year earning in Pakistani organizations.

Hauser (2013) conducted research to examine whether the dividend policy of a firm changes during the financial crises. Panel logistic regression model is applied to industrial firms of the USA during the period 2006 to 2009. Analysis shows that probability of dividend cut increases significantly during financial crises due to sales growth rate, capital ratio and profitability of the firm.

Najjar \& Belghiter (2011) explored simultaneous relationship between dividend policy and cash holding of 400 nonfinancial firms of the UK. Single equation model, simultaneous equation model and dynamic behavior model are applied to determine the influence of cash holding on dividend policy. Findings reveal that the determinants of cash holding are dividends, leverage, growth, size, risk, profitability and working capital. Whereas the determinants of dividend payout are cash, leverage, growth, size, risk, profit.
Although cash holding and dividend policy share the same determinants, they do not affect one another.

Li \& Twite (2009) investigated the probability of dividend payout, various dividend forms and market reaction to different dividend announcements in Chinese capital market. They use a sample of 5153 firm-year dividend announcements by listed Chinese companies from 2003 to 2007. They found that firms with higher profit, higher cash holding, lower leverage, stronger governance, shareholders' protection and subsequent equity offerings are more likely to pay cash dividends. Firms with high level of retained earnings and higher investment in fixed assets are more likely to pay stock dividends. Firms paying stock dividends experience positive market reaction and increased analysts following.

Ahmed and Javid (2009) studied the determinants and dynamics of dividend policy of nonfinancial listed firms of Karachi Stock Exchange for the period 2001 to 2006. For dynamics of dividend payout, the extended model of Linter, Babiak, Fama and proposed model in dynamic setting are applied. The results reveal that nonfinancial listed firms of Pakistan rely on both past dividends and current earnings. However current earnings affect dividend payout more than past dividend payouts. For the determinants of dividend policy panel regression is conducted using independent variables dividend yield, earning per share, major number of shareholders, net earnings, corporate tax, leverage, slack, sales growth, size, market capitalization, market liquidity, return on asset and market to book value. They concluded that firms with stable earnings and profitability pay higher dividends because they can afford higher free cash flows. Ownership concentration and liquidity positively influence dividend decision. Slack, leverage, market capitalization and size have negative influence on dividend decision.

Collins, Saxena \& Wansley (1996) studied the role of insiders in determining dividend 
payout of unregulated firms, utilities firms and financial services firms. It was assumed that the insiders of regulated firms such as utilities and financial service firms play low role in determining dividend policy as compared to unregulated firms. Regression model is developed to determine whether regulation and insiders' role are substitute or complement for financial and utilities firms. Results reveal that regulatory environment enhances the role of insiders while determining the dividend decision of a utility company. For financial service firm insiders' role does not influence dividend payout.

Zaman (2013) studied the impact of profitability, growth and size of 30 listed commercial banks of Dhaka Stock Exchange on dividend payout for the period 2006 to 2012. Multiple regression analysis is applied to gauge the influence of selected factors on dividend payout. Findings reveal that profitability is the stronger determinant of dividend payout as compared to growth and size of the firm. However growth opportunity and size of the firm also significantly predict dividend payout.

Musiega et.al (2013) studied the influence of selected variables on the dividend payout of 30 nonfinancial companies listed at Nairobi Securities Exchange for the period 2007 to 2011. Independent variables include growth, profitability, liquidity, current earning, size and business risk. Multiple regression analysis is applied to determine the impact of selected variables on dividend payout decision. Findings show that profitability, growth opportunities, firm size and business risk are the key determinants of dividend policy

Abdullah, Ismial \& Sadique (2005) studied the influence of selected factors on dividend payout of 174 firms listed on the Malaysian Main Board of Busra for the period 1999 to 2004. The variables selected for the study include leverage, profitability, tangibility, size, growth and liquidity. Regression analysis is applied to measure the influence of selected variables on dividend payout. Size and growth are found to have significant positive impact on dividend payout whereas leverage inversely affects dividend payout.

Gupta and Banga (2010) examined dividend payout of 150 companies from 16 different industries of Bombay Stock Exchange (BSE) 500 index for seven years period from 2001 to 2007. Factor analysis is conducted to determine the key predictors of dividend policy. Leverage, liquidity, profitability, growth and ownership structure are found to be the key factors affecting dividend payout. Regression analysis is conducted to determine the influence of these variables on dividend policy. Leverage and liquidity are found to be the stronger predictors of dividend policy of Indian companies. Leverage has negative association whereas liquidity is positively associated with dividend decisions.

\section{Research Methodology}

This section shades light over the data collection method, dependent \& independent variables of the study, measurement scale of dependent and independent variable and statistical model of the study.

\section{Data}

Five year data are used from published annual reports of pharmaceutical companies listed on Pakistan Stock Exchange.

\section{Variables}

The following are the variables of this study:

\section{Dependent Variable}

Dividend Payout: is the portion of income distributed among ordinary shareholders which is measured as under:

$$
\text { Dividend Payout Ratio }=\text { Cash dividend / }
$$
Net Income * 100

\section{Independent Variables}

The followings are the independent variables of this research: 


\section{Profitability}

Profitability of firm influences dividend payout decision but a different view is found in existing literature. Packing order theory states that firms tend to finance NPV project through retained earnings and hence pay out low and retain more earnings. In contrary, several researchers found that firms with consistent earning pay more as dividend. Profitability is measured as under:

Return on Equity = Net Income $/$ Total Equity

\section{Growth Opportunities}

The more a firm has positive NPV projects to finance, the more company retains income and pays less as dividend. It can be measure in two ways:

Growth Opportunity = Market Value of equity / Book Value of Equity (i.e. PPS / NAVPS)

\section{Risk}

The risk of future cash flows to shareholders reduces when company pays out more as dividend from current income. It is measured by price earning ration:

Risk $=$ Price of Share $/$ Earning per share

\section{Leverage}

The higher the firm is financed with debts, the lower the dividend payout due to debt covenants. It is measured by Debt to equity ratio:

\section{Leverage $=$ Total Debts $/$ Total} Shareholders' Equity

\section{Liquidity}

The more a firm has current assets available to meet its short term obligations, the more company can pay as dividend. Liquidity is measured by current ratio:

$$
\begin{gathered}
\text { Liquidity }=\text { Current Assets } / \text { Current } \\
\text { Liabilities }
\end{gathered}
$$

\section{Firm Size}

Large firms pay more dividends as they have easy access to capital market to raise funds and low dependence on internal funds. According to Joseph, (2001) firm size can be determined by natural logarithm of book value of the firm's total assets.

$$
\text { Firm size }=\text { Natural log of TA }
$$

\section{Audit Type}

Researchers found those firms that are audited by one of the four big audit firms pay more as dividend. Audit type will be represented by dummy variable 1 if audited by big firm and 0 if audited by other audit firms.

\section{Taxation}

Researchers found that when firm's tax liability increases, the dividend payout decreases whereas retained earnings increase. Tax effect can be measured as under:

$$
\text { Tax = Corporate tax / EBT }
$$

\section{Statistical Model}

The following statistical model is developed to measure the impact of selected independent variables on dividend payout. The model is analyzed through bivariate correlation and multiple regression analysis. The following statistical model is used for data analysis:

$$
\begin{gathered}
\mathrm{DP}=\beta_{0}+\beta_{1} \text { prof }+\beta_{2} \mathrm{GO}+\beta_{3} \mathrm{Risk}+ \\
\beta_{4} \text { Liverage }+\beta_{5} \text { Liquidity }+\beta_{6} \mathrm{FS}+\beta_{7} \mathrm{AT}+ \\
\beta_{8} \text { Taxation }+\mathrm{E}
\end{gathered}
$$

Where,

$\beta_{1}$ prof: represents profitability of firm

$\beta_{2} \mathrm{GO}$ : represents growth opportunities of firm

$\beta_{3}$ Risk: represents risk of future cash flows to shareholders

$\beta_{4}$ Liverage: represents leverage of the firm 
$\beta_{5}$ Liquidity: shows the liquidity of the firm

$\beta_{6}$ FS: shows the size of firm

$\beta_{7} \mathrm{AT}$ : represents audit type of the firm

$\beta_{8}$ Taxation: represents taxation of the firm

\section{Data Analysis}

Data analysis section includes the findings of empirical study. Initially, descriptive statistic of dependent and independent variables is given. Then correlation and regression analysis is discussed followed by discussion of results of these analyses.

Descriptive Statistics

Table 1: Descriptive Statistics

\begin{tabular}{|c|c|c|c|c|}
\hline & Mean & Std.Dovition & Skewness & Kurtosis \\
\hline DividendPayout & 11.05 & 21.46 & 1.84 & 2.17 \\
\hline Profitability & 12.76 & 9.60 & -032 & -0.72 \\
\hline Growthopportunity & 2.02 & 1.38 & 1.31 & 1.52 \\
\hline $\mathbf{R}^{-} \times \mathbf{k}$ & 15.56 & 63.24 & 5.27 & 37.79 \\
\hline Leverags & 0.70 & 0.77 & 2.59 & 9.94 \\
\hline Liquidity & 225 & 1.06 & 1.18 & 1.15 \\
\hline Fimsira & 8.78 & 1.05 & -1.03 & -0.25 \\
\hline AuditType & 0.78 & 0.42 & -137 & -0.12 \\
\hline Taxtion & 0.08 & 0.83 & -5.01 & 29.11 \\
\hline
\end{tabular}

According to Table 1, average dividend payout of listed pharmaceutical companies of PSX is 11.05 per share with average deviation of 21.46 rupee per share. Since deviation of dividend payout from mean is high, which suggests that dividend payout of all listed pharmaceutical companies of PSX has much variation. Furthermore, skewness and kurtosis of all independent variables is within acceptable limit of \pm 1.5 (except growth opportunity, leverage and taxation), therefore it can be said that the data are normal.

\section{Bivariate Correlation Test}

Bivariate correlation is applied to check association between dependent \& independent variables and multicollinearity among independent variables. The summarized results of this test are given in Table 2: 
Table 2: Bivariate Correlation

\begin{tabular}{|c|c|c|c|c|c|c|c|c|c|c|}
\hline & & $\begin{array}{c}\text { Dividend } \\
\text { Payout } \\
\end{array}$ & Profitability & $\begin{array}{c}\text { Growth } \\
\text { Opportumity }\end{array}$ & Ri.t & Levernge & $\begin{array}{c}\text { Liquidit } \\
y\end{array}$ & $\begin{array}{l}\text { Fimm } \\
\text { Sixe }\end{array}$ & $\begin{array}{l}\text { Audit } \\
\text { Type }\end{array}$ & Thxation \\
\hline \multirow{3}{*}{$\begin{array}{c}\text { Dividend } \\
\text { Pryout }\end{array}$} & $\begin{array}{c}\text { Pearson } \\
\text { Comelation }\end{array}$ & 1 & .209 & $-34 T^{*}$ & -.037 & .002 & $-333^{*}$ & -.211 & $271^{*}$ & .176 \\
\hline & $\begin{array}{c}\text { Sig } \\
\text { (2-tuiled) }\end{array}$ & & .130 & .010 & .793 & .986 & .014 & .125 & .047 & 203 \\
\hline & $\mathbf{N}$ & 54 & 54 & 54 & 54 & 54 & 54 & 54 & 54 & 54 \\
\hline \multirow{3}{*}{ Profitmbility } & $\begin{array}{c}\text { Pearson } \\
\text { Comelation }\end{array}$ & 209 & 1 & $-393^{*}$ & -.050 & -.073 & .012 & -.038 & $-379^{+*}$ & $391^{* *}$ \\
\hline & $\frac{\text { sig }}{\text { (2-triled) }}$ & .130 & & .003 & .718 & .600 & .934 & .786 & .005 & .003 \\
\hline & $\mathbf{N}$ & 54 & 54 & 54 & 54 & 54 & 54 & 54 & 54 & 54 \\
\hline \multirow{3}{*}{$\begin{array}{c}\text { Growth } \\
\text { Opportunity }\end{array}$} & $\begin{array}{c}\text { Pearson } \\
\text { Comlation }\end{array}$ & $-347^{*}$ & $-393^{* *}$ & 1 & .224 & -.019 & .180 & .070 & 206 & -.251 \\
\hline & $\begin{array}{c}\text { Sig } \\
\text { (2-triled) }\end{array}$ & .010 & .003 & & .104 & .892 & .192 & .613 & .135 & .067 \\
\hline & $\mathbf{N}$ & 54 & 54 & 54 & 54 & 54 & 54 & 54 & 54 & 54 \\
\hline \multirow{3}{*}{ Risk } & $\begin{array}{c}\text { Pearson } \\
\text { Comelation }\end{array}$ & -.037 & -.050 & 224 & 1 & -.124 & .130 & -.016 & .080 & 237 \\
\hline & $\begin{array}{c}\text { sig } \\
\text { (2-triled) }\end{array}$ & .793 & .718 & .104 & & 370 & 348 & .910 & .567 & .085 \\
\hline & $\mathbf{N}$ & 54 & 54 & 54 & 54 & 54 & 54 & 54 & 54 & 54 \\
\hline \multirow{3}{*}{ Leverage } & $\begin{array}{c}\text { Pearson } \\
\text { Comelation }\end{array}$ & .002 & -.073 & -.019 & -.124 & 1 & $-.562^{* *}$ & -.194 & -.034 & -.048 \\
\hline & $\begin{array}{c}\text { Sig } \\
\text { (2-triled) }\end{array}$ & .986 & .600 & .892 & .370 & & .000 & .160 & .809 & .731 \\
\hline & $\mathbf{N}$ & 54 & 54 & 54 & 54 & 54 & 54 & 54 & 54 & 54 \\
\hline \multirow{3}{*}{ Liquidity } & $\begin{array}{c}\text { Pearson } \\
\text { Comelation }\end{array}$ & $-333^{*}$ & .012 & .180 & .130 & $-.562^{+4}$ & 1 & $288^{*}$ & .027 & -.015 \\
\hline & $\begin{array}{c}\text { Sig } \\
\text { (2-triled) }\end{array}$ & .014 & .934 & .192 & .348 & .000 & & .034 & .847 & .914 \\
\hline & $\mathbf{N}$ & 54 & 54 & 54 & 54 & 54 & 54 & 54 & 54 & 54 \\
\hline \multirow{3}{*}{ Fim Size } & $\begin{array}{c}\text { Pearson } \\
\text { Comrlation }\end{array}$ & -.211 & -.038 & .070 & -.016 & -.194 & $288^{*}$ & 1 & -.204 & -.127 \\
\hline & $\begin{array}{c}\text { Sig } \\
\text { (2-triled) }\end{array}$ & .125 & .786 & .613 & .910 & .160 & .034 & & .140 & 360 \\
\hline & $\mathbf{N}$ & 54 & 54 & 54 & 54 & 54 & 54 & 54 & 54 & 54 \\
\hline \multirow{3}{*}{ Andit Type } & $\begin{array}{c}\text { Pearson } \\
\text { Comclation }\end{array}$ & $271^{*}$ & $-379^{* *}$ & 206 & .080 & -.034 & .027 & -204 & 1 & -.023 \\
\hline & $\begin{array}{c}\text { Sig } \\
\text { (2-triled) }\end{array}$ & .047 & .005 & .135 & .567 & .809 & .847 & .140 & & .871 \\
\hline & $\mathbf{N}$ & 54 & 54 & 54 & 54 & 54 & 54 & 54 & 54 & 54 \\
\hline \multirow{3}{*}{ Taxation } & $\begin{array}{c}\text { Pearson } \\
\text { Comelation }\end{array}$ & .176 & $391^{* *}$ & -.251 & .237 & -.048 & -.015 & -127 & -.023 & 1 \\
\hline & $\begin{array}{c}\text { Sig } \\
\text { (2-triled) }\end{array}$ & 203 & .003 & .067 & .085 & .731 & .914 & 360 & .871 & \\
\hline & $\mathbf{N}$ & 54 & 54 & 54 & 54 & 54 & 54 & 54 & 54 & 54 \\
\hline
\end{tabular}

*.Comelation is significant at the 0.05 level (2-tailed).

**. Conrelation is significant at the 0.01 level (2-tailed).

Correlation matrix in Table 2 indicates that dividend payout has the highest correlation of 0.271 and 0.209 with audit type and profitability of the firm respectively. This analysis also reveals that positive relationship exists between taxation \& dividend payout, audit type \& dividend payout and profitability \& dividend payout however only results of audit type are statistically significant. The rest of the variables have not association with dividend payout as per correlation analysis. It can also be observed from Table-2 that some independent variables 
are also associated with each other i.e. data set has multicollinearity problem.

\section{Breusch-Pagan Test}

Breusch-Pagan test is applied to check Heteroscedasticity i.e. to check whether variance of error term of each observation is equal or not. The following Table-3 shows the summarized results of Breusch Pagan Test:

Table 3: Breusch-Pagan Test

Dependent Variable: ETSQ

Method:Panel Least Squares

Sample: 20092014

Periodsinchuded:6

Cross-sections included: 9

Total pencl (balenced) obscrvitions: 54

\begin{tabular}{|c|c|c|c|c|}
\hline Variable & Coefficient & Std Enor & t-Statistic & Prob. \\
\hline $\mathbf{C}$ & -79.66906 & 471.9227 & -0.168818 & 0.8667 \\
\hline PROFITABIIITY & 9.320382 & 5.890925 & 1.582159 & 0.1206 \\
\hline GROWTHOPPORTUNITY & -76.19386 & 38.16838 & -1.996256 & 0.0520 \\
\hline RISK & -0.022714 & 0.780238 & -0.029112 & 0.9769 \\
\hline LEVER AGE & -172.9125 & 72.24943 & -2.393272 & 0.0209 \\
\hline LIQUIDITY & -168.4398 & 54.34759 & -3.099306 & 0.0033 \\
\hline FIRMSIZE & 62.74005 & 46.88482 & 1339174 & 0.1876 \\
\hline AUDITTYPE & 435.1643 & 1222596 & 3.559346 & 0.0009 \\
\hline TAXATION & -40.60070 & 63.55764 & -0.638801 & 0.5262 \\
\hline R-squared & 0.400802 & Mean dependent var & & 2712454 \\
\hline Adjusted R-squared & 0.294278 & S.D. dependent var & & 392.1556 \\
\hline SE. of rcgrcssion & 329.4393 & Akriks info critcrion & & 14.58367 \\
\hline Sum squared resid & 4883861. & Schwarz criterion & & 14.91517 \\
\hline Iog likelihood & -384.7592 & Hannan-Quinn criter- & & 14.71152 \\
\hline F-statistic & 3.762543 & Durbin-Whatson stat & & 1943935 \\
\hline Prob(F-statistic) & 0.001895 & & & \\
\hline
\end{tabular}

The above table shows that F-Statistic value is 3.762 and the sig value is 0.00189 . Since the Sig value is below 0.05 , we can conclude that error term of each observation is not equal and data set has problem of Heteroscedasticity.

\section{Durbin Watson Test}

Durbin Watson test is applied to check Autocollinearity i.e. To check whether correlation of error term of observations is zero or not. The following table 4 depicts the summarized result of panel least square regression: 
Table 4: Panel Least Square Regression

\begin{tabular}{|c|c|c|c|c|}
\hline $\begin{array}{l}\text { Dependent Variable: DIVIDEND } \\
\text { Method:Panel Least Squares } \\
\text { Semplc: } 20092014 \\
\text { Periods included: } 6 \\
\text { Cross-sections inchded:9 } \\
\text { Total panel (balmnced) observati }\end{array}$ & & & & \\
\hline Variable & Coefficient & Std Enor & tSthtistic & Prob. \\
\hline $\mathbf{C}$ & 21.09829 & 25.84445 & 0.816357 & 0.4186 \\
\hline PROFILABLIIY & 0.574889 & 0.322612 & 1.781986 & 0.0815 \\
\hline GROWTHOPPORTUNITY & -4.227048 & 2.090259 & -2.022260 & 0.0491 \\
\hline RISK & 0.011512 & 0.042729 & 0.269418 & 0.7888 \\
\hline LEVERAGE & -5.597596 & 3.956679 & -1.414721 & 0.1640 \\
\hline LIQUIDIYY & -8.338111 & 2976300 & -2.801502 & 0.0075 \\
\hline FIRMSIZE & -0.357710 & 2567608 & -0.139316 & 0.8898 \\
\hline AUDITTYPE & 21.61607 & 6.695446 & 3.228473 & 0.0023 \\
\hline TAXATION & -0.249962 & 3.480681 & -0.071814 & 0.9431 \\
\hline R-squared & 0.399634 & Mean dependent var & & 11.05130 \\
\hline Adjusted R-squared & 0.292902 & S.D. dependent var & & 21.45517 \\
\hline S.E. of regression & 18.04146 & Aknike info criterion & & 8.774234 \\
\hline Sum squared resid & 14647.25 & Schwraz criterion & & 9.105732 \\
\hline I og likelihood & -227.9043 & Hannan-Quinn criter. & & 8.902080 \\
\hline F-statistic & 3.744279 & Durbin-Watson stat & & 0.356777 \\
\hline Prob(F-stintistic) & 0.001964 & & & \\
\hline
\end{tabular}

The above table shows that Durbin-Watson stats is 0.356 . The lower and upper limit of $\mathrm{d}$ is $1.253 \& 2.747$ respectively, determined through DW stats table using $\mathrm{n}=55, \mathrm{k}=8$

Backward Multiple Regression and $\alpha=0.05$. Since the calculated DW stats lie between 0 to lower limit of $D$, we conclude that positive autocorrelation exists in dataset.

The following tables from 3 to 5 shows the results of backward multiple linear regressions applied in this research:

Table 5: Model Summary

\begin{tabular}{|c|c|c|c|c|}
\hline Model & $\mathbf{R}$ & RSquare & $\begin{array}{l}\text { Adjusted R } \\
\text { Squne }\end{array}$ & $\begin{array}{l}\text { Std Error of the } \\
\text { Esthmate }\end{array}$ \\
\hline 1 & $.632^{a}$ & 399 & 292 & 18.047 \\
\hline 2 & $.632^{b}$ & 399 & 308 & 17.851 \\
\hline 3 & $.632^{c}$ & 399 & 322 & 17.664 \\
\hline 4 & $.631^{d}$ & 398 & 335 & 17.493 \\
\hline 5 & $.609^{\circ}$ & 371 & 319 & 17.703 \\
\hline
\end{tabular}

a. Predictors: (Constant), Audit Type, Taxation, Liquidity, Risk, Firm Size, Growth Opportunity, Leverage, Profitability b. Predictors: (Constant), Audit Type, Liquidity, Risk, Firm Size, Growth Opportunity, Leverage, Profitability 
c. Predictors: (Constant), Audit Type, Liquidity, Risk, Growth Opportunity, Leverage, Profitability

d. Predictors: (Constant), Audit Type, Liquidity, Growth Opportunity, Leverage, Profitability

e. Predictors: (Constant), Audit Type, Liquidity, Growth Opportunity, Profitability

Table 3 shows that total explanatory power of the model is $29.20 \%$ in the presence of all independent variables of the model. Backward linear regression step by step removes the most insignificant independent variables from the model.
Equations $\mathrm{b}$ to e show that the variables taxation, firm size, risk and leverage are respectively removed from the model. Total variation in dividend payout explained by the remaining variables (i.e. audit type, liquidity, growth opportunities \& profitability) is $31.90 \%$. Explanatory power of the model has been risen from $29.20 \%$ to $31.90 \%$ after removing insignificant variables which shows that they cause very little or no change in dependent variable. $F$ value of 7.213 at significance level 0.000 in equation e of Table 4 shows that these results are highly significant.

Table 6: ANOVA $^{\mathrm{f}}$

\begin{tabular}{|c|c|c|c|c|c|c|}
\hline & del & $\begin{array}{l}\text { Sum of } \\
\text { Squares } \\
\end{array}$ & df & $\begin{array}{l}\text { Mean } \\
\text { Square }\end{array}$ & $\mathbf{F}$ & Sig. \\
\hline \multirow{3}{*}{1} & Regression & 974021 & 8 & 1217.526 & 3.738 & $.002^{\mathrm{a}}$ \\
\hline & Residual & 14656.98 & 45 & 325.711 & & \\
\hline & Total & 24397.19 & 53 & & & \\
\hline \multirow{3}{*}{2} & Regression & 9738.81 & 7 & 1391.259 & 4366 & $.001^{b}$ \\
\hline & Residual & 14658.38 & 46 & 318.660 & & \\
\hline & Total & 24397.19 & 53 & & & \\
\hline \multirow{3}{*}{3} & Regression & 9732.69 & 6 & 1622.114 & 5.199 & $.000^{c}$ \\
\hline & Residual & 14664.51 & 47 & 312.011 & & \\
\hline & Total & 24397.19 & 53 & & & \\
\hline \multirow{3}{*}{4} & Regression & 970929 & 5 & 1941.858 & 6.346 & $.000^{d}$ \\
\hline & Residual & 14687.90 & 48 & 305.998 & & \\
\hline & Total & 24397.18 & 53 & & & \\
\hline \multirow{3}{*}{5} & Regression & 9041.49 & 4 & 2260.373 & 7.213 & $.000^{\circ}$ \\
\hline & Residual & 15355.69 & 49 & 313.382 & & \\
\hline & Total & 24397.19 & 53 & & & \\
\hline
\end{tabular}

a. Predictors: (Constant),Andit Type, Taxation, Liquidity, Risk, Fim Size, Growth Opportunity, Leverage, Profitability

b. Predictors: (Constant), Audit Type, Liquidity, Risk, Fim Size, Growth Opportunity, Leverage, Profitability

c. Predictors: (Constant), Andit Type, Liquidity, Risk, Growth Opportnnity, Leverage, Profitability

d. Predictors: (Constant), Andit Type, Liquidity, Growth Opportunity, Leverage, Profitability

e. Predictors: (Constant),Audit Type, Liquidity, Growth Opportunity, Profitability

f. Dependent Variable: Dividend Payout

Table 4 shows that $\mathrm{F}$ value of the model in the presence of all selected independent variables is 3.738 at a significance level of 0.002. Backward linear regression removes insignificant variables taxation, firm size, risk \& leverage from equation $b$ to $e$ respectively. Rise in $\mathrm{F}$ value due to step by step removal of insignificant independent variables is evident of their insignificance. $F$ value of 7.213 at significance level of 0.000 in equation e shows that audit type, liquidity, growth opportunity and profitability are the key determinants of dividend payout in the selected model. 
Thble 7: Coefficients"

\begin{tabular}{|c|c|c|c|c|c|c|c|c|}
\hline & \multirow[t]{2}{*}{ Model } & \multicolumn{2}{|c|}{ Un-standardined Coefifielents } & \multirow{2}{*}{$\begin{array}{c}\begin{array}{c}\text { Standandired } \\
\text { Coefificht: }\end{array} \\
\text { Bdt }\end{array}$} & \multirow[t]{2}{*}{$\mathbf{t}$} & \multirow[t]{2}{*}{ stg } & \multicolumn{2}{|c|}{ Co-linearity Statiotes } \\
\hline & & $\mathbf{E}$ & Std. Rrror & & & & Toloranco & VIF \\
\hline \multirow{9}{*}{1} & (Constant) & 21.15 & 25.87 & & 0.82 & 0.42 & & \\
\hline & Profitmbility & 057 & $\mathbf{0 . 3 2}$ & 026 & 1.78 & 0.08 & 0.64 & 1.56 \\
\hline & $\begin{array}{l}\text { Growth } \\
\text { Oppotunity }\end{array}$ & -422 & 2.09 & -0.27 & -2.02 & 0.05 & 0.74 & 1.35 \\
\hline & Risk & 0.01 & 0.04 & 0.03 & 0.27 & 0.79 & 0.84 & 1.19 \\
\hline & Lewerage & -559 & 3.96 & -0.20 & -1.41 & 0.16 & 0.67 & 1.50 \\
\hline & Linuidity & -833 & 2.98 & -0.41 & -2.80 & 0.01 & 0.62 & 1.61 \\
\hline & Fim Sire & -036 & 2.57 & -0.02 & -0.14 & 0.89 & 0.84 & 1.18 \\
\hline & Tration & -023 & 3.49 & -0.01 & -0.07 & 0.95 & 0.73 & 1.37 \\
\hline & Andit Type & 21.60 & 6.70 & 0.42 & 3.23 & 0.00 & 0.78 & 1.29 \\
\hline \multirow{8}{*}{2} & (Constant) & 21.12 & 25.58 & & 0.83 & 0.41 & & \\
\hline & Pmfithbility & 0.57 & 0.30 & 0.25 & 1.90 & 0.06 & 0.73 & 137 \\
\hline & $\begin{array}{l}\text { Growth } \\
\text { Oppotonity }\end{array}$ & -420 & 2.03 & -0.27 & -2.07 & 0.04 & 0.77 & 1.30 \\
\hline & Risk & 0.01 & 0.04 & 0.03 & 0.26 & 0.79 & 0.93 & 1.08 \\
\hline & Lowerage & -559 & 3.92 & -0.20 & -1.43 & 0.16 & 0.67 & 1.50 \\
\hline & $\begin{array}{l}\text { Linuidity } \\
\end{array}$ & -833 & 2.95 & -0.41 & -2.83 & 0.01 & 0.62 & 1.61 \\
\hline & Fim Size & -0.35 & 2.53 & -0.02 & -0.14 & 0.89 & 0.85 & 1.18 \\
\hline & Andit Type & 21.54 & 6.57 & 0.42 & 328 & 0.00 & 0.79 & 1.27 \\
\hline \multirow{7}{*}{3} & (Constant) & 17.98 & 11.71 & & 1.54 & 0.13 & & \\
\hline & Profit-bility & 0.57 & 0.29 & 0.26 & 1.95 & 0.06 & 0.74 & 1.35 \\
\hline & $\begin{array}{l}\text { Growth } \\
\text { Oppontunity }\end{array}$ & -421 & 2.01 & -0.27 & -2.09 & 0.04 & 0.77 & 1.30 \\
\hline & Rislx & 0.01 & 0.04 & 0.03 & 027 & 0.79 & 0.93 & 1.07 \\
\hline & Leverige & -555 & 3.87 & -0.20 & -1.44 & 0.16 & 0.67 & 1.50 \\
\hline & Liquidity & -8.42 & 2.84 & -0.41 & -2.96 & 0.00 & 0.65 & 1.53 \\
\hline & Andit Type & 21.78 & 6.28 & $\mathbf{0 . 4 3}$ & 3.47 & 0.00 & 0.85 & 1.18 \\
\hline \multirow{6}{*}{4} & (Constant) & 17.82 & 1158 & & 1.54 & 0.13 & & \\
\hline & Profitnbility & 0.58 & 0.29 & 0.26 & 1.98 & 0.05 & 0.74 & 1.35 \\
\hline & $\begin{array}{l}\text { Growth } \\
\text { Opportunity }\end{array}$ & -4.10 & 1.95 & -0.26 & -2.10 & 0.04 & 0.80 & 1.25 \\
\hline & Lewerige & -5.64 & 3.82 & -0.20 & -1.48 & 0.15 & 0.67 & 1.49 \\
\hline & Liquidity & -8.40 & 2.82 & -0.41 & -2.98 & 0.00 & 0.65 & 1.53 \\
\hline & Andit Type & 21.86 & 6.22 & 0.43 & 3.52 & 0.00 & 0.85 & 1.18 \\
\hline \multirow{5}{*}{5} & (Constant) & 8.29 & 9.73 & & 0.85 & 0.40 & & \\
\hline & Profitmbility & 0.60 & 0.29 & 0.27 & 2.05 & 0.05 & 0.75 & 1.34 \\
\hline & $\begin{array}{l}\text { Growth } \\
\text { Opportanity }\end{array}$ & -433 & 1.96 & -0.28 & -2.20 & 0.03 & 0.81 & 1.24 \\
\hline & Linquidity & -6.05 & 2.35 & -0.30 & -2.57 & 0.01 & 0.96 & 1.04 \\
\hline & Andit Type & 22.43 & 6.28 & 0.44 & 3.57 & 0.00 & 0.85 & 1.17 \\
\hline
\end{tabular}

a Dependent Variable: Dividend Payout

Table 5 reveals that in the absence of all independent variables, dividend payout of pharmaceutical companies of Pakistan stock exchange is 8.29 rupees per share at $96 \%$ confidence interval, as shown in equation 5. Slope coefficient of profitability shows that with 1 rupee increase in Net income of pharmaceutical companies, dividend payout increases by 0.60 rupees at $95 \%$ confidence interval. Slope coefficient of growth opportunities shows that 1 rupee increase in growth opportunity reduces dividend payout by 4.33 per share with $3 \%$ error chances. Slope coefficient of liquidity shows that with the increase in current ratio by 1 unit, dividend payout reduces by 6.05 rupee per share at $99 \%$ confidence interval. Slope coefficient of audit type shows positive relationship of dividend payout and audit type i.e. the firm which is audited by big 4 audit companies pays more dividend than the ones which are not audited by big 4 audit firms.

\section{Discussion and analysis}

Regression results in equation e of table 3 indicate that audit type, liquidity, growth opportunities \& profitability are the key determinants of dividend payout which cause $31.90 \%$ variation in dividend payout 
decisions of pharmaceutical companies of PSX. Other variables including taxation, risk, firm size, and leverage are insignificant in impacting dividend payout policy of pharmaceutical companies of PSX.

The findings of this research highlight the following:

\section{Hypothesis 1}

Profitability of firm is significant in influencing dividend payout with $t$ value above 2 and sig value below 0.05 , as shown in equation 5 of table 5 . This rejects null hypothesis 1 and shows that profitability of a firm positively and significantly impacts dividend payout of a firm. This research finding conforms with a number of studies such as Abor and Bokpin, 2010, Mehta, 2012, Zamer et al, 2013, Hauser, 2013, Najjar\&Belghiter 2011, Ahmed and Javid, 2009.

\section{Hypothesis 2}

Growth opportunity of firm is significant in influencing dividend payout with $t$ value above 2 and sig value below 0.05 , as shown in equation 5 of table 5 . This rejects null hypothesis2 and shows that growth opportunity of a firm negatively and significantly impacts dividend payout of a firm. Since in order to finance expected growth a company needs to hold -on its profit rather than distribute it as a whole. These findings are in conformity with Ehsan, Khalid and Akhter (2011) study on Pakistan stock exchange taking in to consideration 100 non-financial listed companies.

\section{Hypothesis 3}

Risk of future cash flows to shareholders of firm is insignificant in influencing dividend payout with $t$ value above 2 but also sig value above 0.05 , as shown in equation 3 of table 5. This retains null hypothesis 3 and shows that risk of future cash flows to shareholders of a firm is insignificant in influencing dividend payout of a firm. These findings are in conformity with Mehta, (2011) and Jozwiak (2014) research studies on Abu Dhabi and Warsaw stock exchanges respectively.

\section{Hypothesis 4}

Liquidity of firm is significant in influencing dividend payout with $t$ value above 2 and sig value below 0.05 , as shown in equation 5 of table 5 . This rejects null hypothesis 4 and shows that liquidity of a firm significantly impact dividend payout of a firm. This finding is consistent with Veit and Powell (2001) study conducted on Nasdaq firms in which they stated that if the firm wanted to maintain high liquidity then they tends to lower payout ratio and on contrary increase retention of corporate profit.

\section{Hypothesis 5}

Size of firm is insignificant in influencing dividend payout with $t$ value below 2 and sig value above 0.05 , as shown in equation 2 of table 5. This retains null hypothesis 5 and shows that risk of future cash flows to shareholders of a firm is insignificant in influencing dividend payout of a firm. Moradi, Salehi and Honarmand (2010) investigation in to all companies listed in Tehran Stock Exchange also revealed the same findings.

\section{Hypothesis 6}

Leverage of firm is insignificant in influencing dividend payout with $\mathrm{t}$ value below 2 and sig value above 0.05 , as shown in equation 4 of table 5 . This retains null hypothesis 6 and shows that leverage of a firm is insignificant in influencing dividend payout of a firm. This finding is also consistent with Mehta (2012) investigation in to companies listed in Abu Dhabi stock exchange.

\section{Hypothesis 7}

Taxation of firm is insignificant in influencing dividend payout with $t$ value below 2 and sig value above 0.05 , as shown in equation 1 of table 5. This retains null hypothesis7 and shows that taxation of a firm is insignificant in influencing dividend payout of a firm. 


\section{Hypothesis 8}

Audit type of firm is highly significant in influencing dividend payout with $t$ value above 2 and sig value below 0.05 , as shown in equation 5 of table 5 . This rejects null hypothesis 8 and shows that audit type (i.e. firm audited by big 4 audit firms or other firms) positively and significantly impacts dividend payout of a firm. Significant relation in between type of audit and dividend policy of the firm has also previously been verified with a study conducted on 30 listed companies in Ghana stock exchange (Nuhu, 2014).

\section{Recommendations $\quad \& \quad$ Policy Implications:}

In the light of the research, the following recommendations can be made to stakeholders of pharmaceutical companies in Pakistan:

1. Pharmaceutical companies' managementis recommended to get their audit conducted by one of the big five audit firms to ensure maximum dividend to their investors.

2. Investors in pharmaceutical sector are recommended to invest in companies that consistently maintain high profits in order to earn high dividends.

3. Pharmaceutical companies' management is recommended to maintain low liquidity ratio to ensure maximum returns to investors.

4. Brokerage houses are recommended to advise their clients to invest in pharmaceutical companies that have low growth opportunities to earn high dividends.

\section{Conclusion}

This research investigated the determinants of the dividend payout of listed pharmaceutical companies of Pakistan Stock Exchange. Five years data are studied from published annual reports of nine pharmaceutical companies of PSX from period 2009 to 2014.Dividend payout is the dependent variable of this research and profitability, growth opportunity, risk, leverage, liquidity, firm size, taxation and audit type are independent variables. Correlation analysis is applied to measure association between dependent and independent variables. Backward Multiple Regression is applied to measure the impact of selected independent variables on dividend payout decisions of pharmaceutical companies of PSX.

Findings of this research can be summed up as audit type, liquidity, growth opportunities \& profitability which are the key determinants of dividend payout of pharmaceutical companies of PSX. 31.90\% variation in dividend payout is caused by these variables. Other independent variables including taxation, risk, firm size, and leverage are insignificant in predicting dividend payout decisions of pharmaceutical companies of PSX.

In the light of these findings, it can be concluded that firms audited by big 4 audit firms are most likely to pay more dividends. Firms with high growth opportunities pay fewer dividends and firms with low liquidity or earning high profits pay more dividends. It is worthwhile for investors in pharmaceutical companies of PSX to take into account these four factors.

\section{References}

Abor, J. \&Bokpin, G. A. (2010). Investment opportunities, corporate finance, and dividend payout policy: Evidence from emerging markets. Studies in Economics and Finance, 27 (3), 180 - 194.

Abdullah, WW, Ismail, N and Sadique, R. B. (2005) 'Determinants of Corporate Dividend Policy,' A Malasian Perspective. Selangor: University Teknologi Mara.

Ahemd, Hand Javid, A. (2009) 'Dynamics and Determinants of Dividend Policy in Pakistan: Evidence from Karachi stock Exchange Non-Financial Listed Firms,' Journal of Independent Studies and Research, 7(1), 1-30. 
Al-Najjar, B and Belghitar, Y. (2011)'Corporate Cash Hodlings and Dividend Payments: Evidence from Simultaneous Analysis.'Managerial and Decision Economics, 32, 231-241.

Alzomaia, TS and Al-Khadhiri, A. (2013) 'Determination of Dividend Policy: The Evidence from Saudi Arabia,'International Journal of Business and Social Science, 4(1), 181-191.

Arif, A and Akbar, F. (2013)'Determinants of Dividend Policy: A Sectoral Analysis from Pakistan,'International Journal of Business and Behavioral Sciences, 3(9), 1633.

Brealey, RA, Myers, SC, \& Allen, F. (2008)Principles of Corporate Finance 9, McGraw-Hill Education, New York.

Bryman, A and Bell, E. (2007) Business Research Methods, Oxford University Press, New York.

Collins, C., Saxena, AK and Wansley, JW. (1996) 'The Role of Insiders and Dividend Policy: A Comparison of REgulated and Unregulated Firms,'Journal of Financial and Strategic Decisions, 9(2), 1-9.

Ehsan.S., Khalid.M., Akhter,.W.(2011).Dividend Payout in Firms with Growth Potentials In Presence of Insider Ownership Concentration, Sci.Int. (Lahore), 26(4), 1723 -1730, 2014

Gill, A., Biger, Nand Tibrewala, R. (2010)'Determinants of Dividend Payout Ratios: Evidence from United States,'The Open Business Journal, 3, 8-14.

Gupta, A and Banga, C. (2010) 'The Determinants of Corporate Dividend Policy,' Decision, 37(2), 63-77.

Hauser, R. (2013)`Did Dividend Policy Changed during Financial Crises,'Managerial Finance, 39(6), 584-606.

Jozwiak, BK (2014)'Determinants of Dividend Policy: Evidence from Polish Listed Companies,'Procedia Economics and Finance, 473-477.
Khan, N., Burton, B and Power, D. (2011)'Managerial Views about dividend Policy in Pakistan,'Managerial Finance, 37(10), 953-970.

Li, M., Twite, G. J., He, Xand Shi, J. (2009)'Determinants of Dividend Policy in Chinese Firms: Cash Versus Stock Dividends,'SSRN Electronic Journal.

Maladjian, Cand Khoury, ER. (2014) 'Determinants of the Dividend Policy: An Empirical Study on the Lebanese Listed Banks,'International Journal of Economics and Finance, 6(4), 240-256.

Mehta, A. (2012)'An Empirical Analysis of Determinants of Dividend Policy - Evidence from the UAE Companies.'Global Review of Accounting and Finance, 3(1), 18-31.

.Moradi,.M., Salehi,M., and Honarmand.S., 2010 "Fctors Affecting Dividend Policy, Empirical Evidence of Iran" UKD/UDC:336.76(55).

Musiega, M., Alala, OB., Douglas, M., Christopher, MO and Robert, E. (2013)'Determinants of Dividend Payout Policy Amont Non Financial Firms On Nairobi Securities Exchange, Kenya,'International Journal of Scientific \& Technology Research, 2(10), 253-266.

Nuhu, E. (2014) 'Revisiting the Determinants of Dividend Payout Ratios in Ghana,' International Journal of Business and Social Science, 5(8(1)), 230-238.

Rafique, M. (2012) 'Factors Affecting Dividend Payout: Evidence From Listed Non-Financial Firms of Karachi Stock Exchange,'Business Management Dynamics, 1(11), 76-92.

Sharon, LK. (2005)'What Factors Motivate The Corporate Dividend Decision?'ASBBS E-Journal, 1(1), 97-107.

Veit E.T and Powell ,2001 "Factors Influencing Dividend Policy Decisions of Nasdaq Firms , The financial Review, Eastern Finance Association.

Zama, S. (2013),'Determinants of Dividend Policy of A Private Commercial Bank in Bangladesh: Which is The Strongest, 
Profitability, Growth or Size?'Proceedings of 9th Asian Business Research Conference, BIAM Foundation, Dhaka,Bangladesh, 2021.
Zameer, H., Rasool, S., Iqbal, S and Arshad, U. (2013)'Determinants of Dividend Policy: A Case of Banking sector in Pakistan,'Middle-East Journal of Scientific Research, 18(3), 410-424. 